\title{
ETNOMATEMATIKA MOTIF CEPLOKAN BATIK YOGYAKARTA DALAM PENINGKATAN PEMAHAMAN KONSEP MATEMATIKA SISWA
}

\author{
Siska Andriani ${ }^{1}$, Indri Septiani ${ }^{2}$ \\ ${ }^{1,2}$ Program Studi Pendidikan Matematika Fakultas Tarbiyah dan Keguruan \\ UIN Raden Intan Lampung \\ siskaandriani@radenintan.ac.id
}

Received : 28/10/2019

Accepted : 29/01/2020

Published : 31/01/2020

\begin{abstract}
Understanding a concept is a very important aspect in learning, by understanding the concept students can develop their abilities in every material taught. This research aims to improve students' understanding of mathematical concepts, especially in transformation geometry so it's given a treatment of learning mathematicsby utilizing culture, that is at batik motif of Yogyakarta. Ethnomatematics as a media in mathematics learning also aims to introduce and preserve the culture that exists in Indonesia. This research is conducted at SMA N 01 Bangunrejo, Central Lampung Regency, Lampung. This research is a quasi-experimental study involving a sample of 41 students divided into 2 classes, those are the control class and the experimental class. The collected data are analyzed using the $T$ test. Based on the results of the study it is concluded that there is an increasing in understanding of the geometry concept of ethnomatemic transformation in Yogyakarta's ceplokan batik motif in class XI where the $T$ value was obtained $=3.03$ and $P-$ Value $=0.002$, because the value of $P-$ Value less than $\alpha$, it can be concluded that ethnomatemics in Yogyakarta's ceplokan batik motif can increase the understanding of students' mathematical concepts.
\end{abstract}

Keywords: Ethnomatematics, Concept Understanding, Batik Ceplokan.

\begin{abstract}
Abstrak
Pemahaman konsep merupakan suatu aspek yang sangat penting dalam pembelajaran, dengan memahami konsep siswa dapat mengembangkan kemampuannya dalam setiap materi yang diajarkan.Penelitian ini bertujuan untuk meningkatkan pemahaman konsep siswa terhadap konsep matematika terutama pada geometri transformasi sehingga diberikan perlakuan pembelajaran matematika dengan memanfaat budaya, yaitu pada motif batik yogyakarta. Etnomatematika sebagai media dalam pembelajaran matematika juga bertujuan untuk mengenalkan dan melestarikan budaya yang ada di Indonesia. Penelitian ini di lakukan di SMA N 01 Bangunrejo, Kabupaten Lampung Tengah, Lampung. Penelitian ini merupakan penelitian eksperimen semu dengan melibatkan sampel sebanyak 41 siswa yang terbagi menjadi 2 kelas, yaitu kelas kontrol dan kelas eksperimen. Data yang terkumpul dianalisis menggunakan . Berdasarkan hasil penelitian disimpulkan bahwa ada peningkatan pemahaman konsep geometri transformasi bermuatan etnomatematika pada motif batik ceplokan yogyakarta pada siswa kelas XI dimana diperoleh nilai $T=3,03$ dan $P-$ Value $=0,002$ karena nilai $P$-Value kurang dari $\alpha$ maka dapat disimpulkan bahwa etnomatematika pada motif ceplokan Yogyakarta dapat meningkatkan memahaman konsep matematika siwa.
\end{abstract}

Kata Kunci: Etnomatematika, Pemahaman Konsep, Batik Ceplokan

\section{Pendahuluan}

Banyak orang yang menganggap bahwa matematika tidak hanya sekedar menghitung dan bermain dengan angka-angka, padahal banyak hal yang dapat diambil dari pelajaran matematika. Sebagaimana halnya dengan musik, matematika juga tidak hanya bergelut 
dengan rumus-rumus dan angka-angka. Matematika juga menuntut kemampuan berpikir eskploratif dan inovatif. Menurut Suherman dalam (Syarifudding dkk, 2014: 18) pembelajaran matematika merupakan suatu prosedur pembelajaran dimana siswanya dengan antusias dapat mengkontruksi melalui pengalaman yang mereka miliki sebelumnya. Oleh karena itu, pembelajaran matematika dijadikan sebagai proses pembentukan pola pikir dalam menalar hubungan antara suatu konsep dengan konsep lainnya. Pembelajaran matematika juga berkaitan dengan hubungan-hubungan serta simbol-simbol yang bisa dikaitkan dengan kenyataannya. Belajar matematika berhubungan dengan apa dan bagaimana penggunaannya dalam pembuatan keputusan suatu permasalahan.

Tujuan dari pembelajaran matematika menurut Depdiknas (Zevika dkk, 2014: 45) salah satunya adalah agar siswa memiliki keterampilan dalam menginterpretasikan konsep matematika, kemampuan dalam menjelaskan hubungan antar konsep serta kemampuan dalam mengimplementasikan konsep atau algoritma secara fleksibel, cermat, efektif, dan tepat dalam memecahkan suatu permasalahan. Berdasarkan penjelasan diatas dapat disimpulkan bahwa salah satu tujuan utama dalam pembelajaran matematika di sekolah yaitu pengembangan kemampuan pemahaman konsep siswa. Kurikulum 2013 dapat menumbuhkan keahlian belajar yang memberikan kesempatan ekstensif bagi siswa agar mengerti dan menginterpretasikan seni budaya Indonesia (Suhartini \& Martyanti, 2017: 105). Menurut Ekowati, dkk (2017: 716-717) dalam pelaksanaan pembelajarannya, konsep matematika dikenal dengan penguasaan rumus-rumus. Berdasarkan penilaian di kelas dalam 10 tahun terakhir, kebanyakan siswa mengartikan matematika hanya melalui keabsurdannya. Pembelajaran matematika harus dilakukan sefaktual mungkin bagi siswa, salah satunya dengan menggunakan kebijakan lokal atau bisa disebut dengan etnomatematika. Etnomatematika merupakan suatu pembelajaran tentang matematika yang muncul dengan menalar dan memahami sistem matematika pada budaya yang digunakan. Kegiatan matematika biasanya dianggap absurd oleh siswa. Jika matematika dikaitkan dengan unsur budaya lokal maka akan terlihat lebih konkret.

Etnomatematika sangat berperan untuk melestarikan budaya asli agar budaya baru yang muncul tidak menghilangkan budaya asli. Etnomatematika dalam pendidikan juga sangat berperan dalam pembelajaran, hal ini dikarenakan banyak siswa yang membutuhkan pengajaran yang lebih menarik agar matematika yang dianggap sukar oleh siswa bisa lebih mudah untuk dipahami, dan suatu pengetahuan akan menjadi lebih bermakna bagi siswa dalam tahap pembelajarannya dikaitkan dengan konteks atau permasalahan dalam kehidupan nyata. 
Oleh sebab itu, matematika dapat digunakan untuk membantu pemecahan masalah dalam kehidupan sehari-hari baik masalah sosial, ekonomi budaya, serta memperbaiki akhlak peserta didik. Menurut pendapat dari Walle menyebutkan bahwa kemampuan matematika dapat membuka pintu produktif untuk masa depan, namun jika tidak memiliki kemampuan matematika dapat menutup pintu masa depan. Matematika yang bernuansa budaya juga dapat memberikan kontribusi yang besar, baik dari segi pembelajaran maupun juga untuk pengenalan budaya serta dapat melestarikan itu sendiri, agar budaya tradisional Indonesia tidak terkikis dan akan terus menjadi warisan yang dapat berkembang serta dilestarikan oleh generasi bangsa. hal inilah yang mendasari adanya penelitian ini dimana motif batik ceplokan yogyakarta sebagai medianya.

Motif batik Ceplokan merupakan pola batik kuno pada hiasan arca dalam Candi Hindu dan Budha dengan bentuk persegi, lingkaran, binatang, bentuk-bentuk tertutup serta garisgaris miring. Ada beberapa jenis desain geometris pada batik Yogyakarta motif ceplok ini, dianataranya berdasarkan pada bentuk bunga mawar yang melingkar, bintang ataupun bentuk kecil lainnya, serta keseluruhannya membentuk pola simetris. Salah satu ciri khas yang dapat menunjukan bahwa batik ceplokan berasal dari Yogyakarta adalah dari warnanya yang lebih terang, dan hal ini jugalah yang membedakan antara batik Yogyakarta dan batik Solo. Unsur pokok seni rupa pada Batik Yogyakarta motif ceplokan adalah dari kombinasi warna yaitu menggunakan warna-warna yang lebih terang serta coraknya beraturan dan tersusun secara geometris, dari garis, bidang dan titiknya sehingga dapat menciptakan suatu keindahan yang utuh dan teratur.

Batik Yogyakarta motif ceplokan ini dapat mendeskripsikan bahwa masyarakat Yogyakarta telah memanfaatkan ilmu matematika dalam kelangsungan hidupnya, khususnya dalam menciptakan keindahan secara utuh dan teratur pada lukisan batik dengan menentukan paduan warna, bidang, titik dan garis serta komposisi yang menjadi ciri khasnya. Berdasarkan pemaparan ini maka peneliti tertarik untuk mengadakan penyelidikan mengenai konsepkonsep matematika yang terdapat pada motif Batik Ceplokan dari Yogyakarta dalam hubungannya dengan geometri transformasi.

Melalui artikel ini diharapkan karya seni motif batik ceplokan dari Yogyakarta ini dapat digunakan dalam proses pembelajaran geometri trasformasi, digunakan sebagai sumber belajar untuk menambah pengetahuan dan motivasi belajar, serta digunakan untuk mengukur bagaimanakah pemahaman konsep siswa. Setelah menggunakan etnomatematika pada motif batik ceplokan dari yogyakarta ini, apakah ada peningkatan hasil belajar siswa pada materi geometri transformasi. 


\section{Metode Penelitian}

Penelitian ini dilaksanakan di SMA Negeri 01 Bangunrejo, populasi yang digunakan dalam penelitian ini ialah siswa kelas XI yang terdiri dari 9 kelas. Sampelnya adalah siswa kelas XI MIPA 1 sebagai kelas kontrol dan XI MIPA 2 sebagai kelas eksperimen. Variabel bebasnya yaitu pemecahan masalaha matematika siswa dalam penggunaan etnomatematika siswa pada mata pelajaran geometri transformasi. Pengukurannya berdasarkan skor tes kemampuan pemecahan masalah matematika siswa. Sedangakan variabel terikatnya adalah hasil belajar siswa yaitu dengan melihat hasil belajar siswa yaitu dengan melihat hasil tes evaluasi pada akhir pembelajaran, etnomatematika pada motif ceplokan batik yogyakarta sebagai variabel perantaranya.

Penelitian ini dilakukan dalam 4 tahap. Tahap pertama ialah perencanaan awal, merancang kelas yang akan dijadikan sampel dan membuat instrumen yang akan digunakan untuk penelitian. Tahap kedua ialah implementasi tindakan, dilaksanakan proses pembelajaran menggunakan etnomatematika pada motif batik ceplokan yang berasal dari yogyakarta. Tahap selanjutnya ialah observasi dan interpretasi siswa selama proses pembelajaran di kelas. Tahap yang terakhir ialah menganalisis dan merefleksi, pada tahap ini dilakukan kegiatan menganalisis dan mengolah data yang diperoleh dari hasil penelitian. Data yang diperoleh selanjutnya dikumpulkan kemudian disimpulkan apakah ada peningkatan pemahaman konsep siswa setelah menggunakan motif batik ceplokan yang dilihat dari hasil belajar siswa melalui soal tes yang diberikan di akhir pembelajaran. Metode pengumpulan data dalam penelitian ini ialah tes dan dokumentasi. Teknik analisis data menggunakan uji One Simple $t$ Test dimana sebelumnya dilakukan uji prasyarat terlebih dahulu yaitu dengan menggunakan uji normalitas dan homogenitas dari hasil nilai pretest dan uji homogenitas dari nilai postest, selisih postest dan pretest (peningkatan). Uji normalitas dan uji homogenitas menggunakan Minitab 16. Untuk melihat apakah ada peningkatan pemahaman konsep matematika siswa yang dilihat dari hasil belajar siswa.

Uji ketuntasan kemampuan koneksi matematika digunakan uji satu pihak menggunakan Minitab dengan analisis One Simple $t$ Test. Uji selisih dua proporsi untuk mengetahui efektif atau tidaknya perangkat pembelajaranyang diujicobakan dan membandingkan banyaknya siswa yang memperoleh nilai rata-rata kemampuan koneksi matematika mencapai batas tuntas pemahaman konsep matematika antara kelas eksperimen dengan kelas kontrol. Uji peningkatan pemahaman konsep matematika dengan menggunakan uji beda rata-rata dari selisih postest dan pretest serta uji paired sample t-test. 


\section{Hasil dan Pembahasan}

Geometri trasformasi secara mendasar merupakan hasil alami terhadap alam semesta fisik. Menurut pendapat Michael Hvidcen pada tahun 2012, geometri berasal dari sebuah pandangan garis dan pola geometris yang telah digunakan di piramida mesir kuno untuk mewakili konsep-konsep abstrak, konsep yang diungkapkan melalui pembangunan objek yang memiliki bentuk geometris. Geometri juga merupakan sistem matematika yang mempelajari unsur serta hubungan yang ada diantara unsur tersebut. Benda-benda imajiner yang menjadi unsur dasar geometri diantaranya titik, garis, bidang dan ruang. Berdasarkan unsur-unsur inilah didefinisikan pengertian-pengertian baru atau berdasarkan pada pengertian baru sebelumnya.

Geometri transformasi bagian dari ilmu geometri yang mempelajari transformasi (perubahan), baik perubahan letak maupun penyajiannya menggunakan gambar dan matrik. Secara matematis transformasi pada suatu bidang $R^{2}$ merupakan fungsi bijektif (surjektif dan injektif) dengan daerah $R^{2}$ dan daerah nilainya juga $R^{2}$ Transformasi terdiri atas translasi (perpindahan), rotasi (perputaran), refleksi (pencerminan), dan dilatasi (perbesaran), sedangkan geometri transformasi pada motif desain batik ceplokan meliputi berbagai desain geometris, sering didasarkan pada bentuk mawar melingkar, bintang atau bentuk kecil lainnya, serta membentuk pola secara keseluruhan simetris pada kain.

Adapun gambar dari Motif Batik Ceplokan Yogyakarta adalah sebagai berikut:

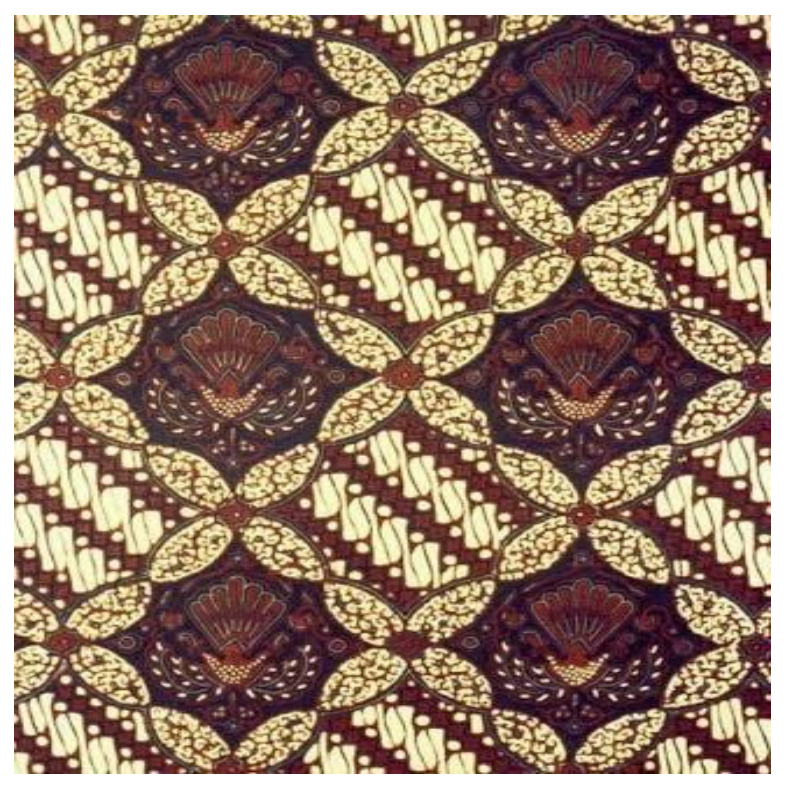

Gambar 1 Motif Batik Ceplokan

Etnomatematika pada Karya Seni Batik Ceplokan berdasarkan penjelasan sebelumnya bahwa bentuk geometri yang terdapat pada batik berupa titik, garis dan bidang datar. Bidang datar tersebut misanya elips, lingkaran, segi empat dan sebagainya. Corak estetis pada batik 
dihasilkan melalui transformasi titik, garis atau bidang datar melalui translasi (perpidahan) dan refleksi (pencerminan).

a. Implementasi Translasi (pergeseran) pada Motif Batik Ceplokan

Translasi (pergeseran) merupakan suatu transformasi dengan memindahkan semua titik pada bidang dengan jarak dan arah yang sama. Dalam matematika apabila ada dua titik $A$ dan $B$ maka jika $A^{\prime \prime}$ dan $B^{\prime \prime}$ adalah hasil geserannya maka $\overrightarrow{A B}=\overrightarrow{A^{\prime \prime} B^{\prime \prime}}$, dimana $\overrightarrow{A B}$ dibaca vektor $A B$ (ruas garis berarah). Berdasarkan definisi pergeseran yang menggunakan istilah ruas garis berarah, ruas garis berarah (vektor) merupakan suatu besaran yang mempunyai besar dan arah.

Dalam motif ceplokan ini, motif dasarnya adalah dua kurva sama besar yang saling berhadapan dan membentuk persegi (bujur sangkar).

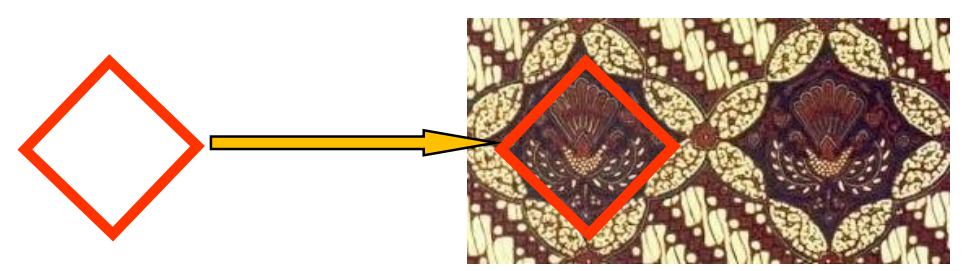

Gambar 2

$>\quad$ Kemudian dipindahkan atau ditranslasikan dengan skala sebanyak $n$ terhadap garis horizontal tanpa menghilangkan kurva pertama (Gambar 3)

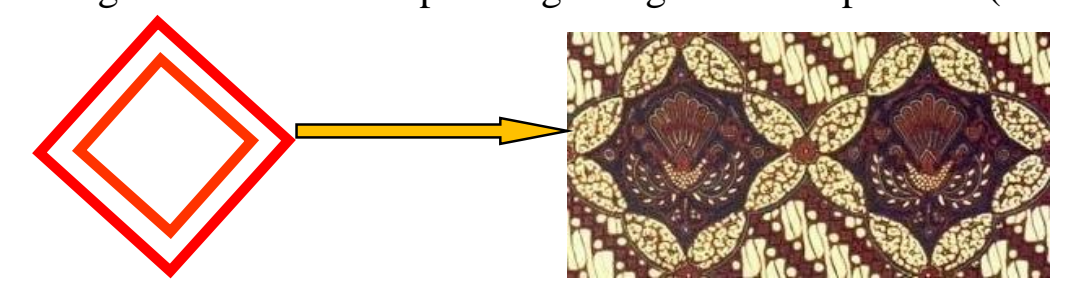

Gambar 4

$>\quad$ Sehingga didapat motif ceplokan seperti pada gambar 2.

b. Implementasi Refleksi (Pencerminan) pada Motif Batik Ceplokan

Pencerminan merupakan suatu transformasi dengan memindahkan setiap titik pada bidang dengan menggunakan sifat bayangan cermin dari titik-titik tersebut. Refleksi suatu bangun geometri merupakan metode pencerminan setiap titik bangun geometri terhadap garis tertentu yang biasa dinamakan sumbu simetri. Jika suatu bangun geometri dicerminkan terhadap suatu garis tertentu, maka menghasilkan bayangan yang sama dengan bangun awal. Pada matematika dapat didefinisikan bahwa pencerminan terhadap garis $s$ adalah suatu penetapan yang memenuhi untuk sembarang $A$ dibidang $V$ berlaku:[5] 


$$
M_{X}(A)\left\{\begin{array}{c}
A, \forall A=P \\
B \text { dengan s sumbu } A B, \\
\text { jika A tidak di } S
\end{array}\right.
$$

Pencerminan jika di aplikasikan pada Batik Yogyakarta Motif Cepokan maka akan mendapatkan hasil ataupun ilustrasi atau gambaran seperti pada gambar dibawah:

Bentuk dasarnya adalah motif bunga yang terdir dari 4 (empat) bentuk elips seperti pada Gambar 5

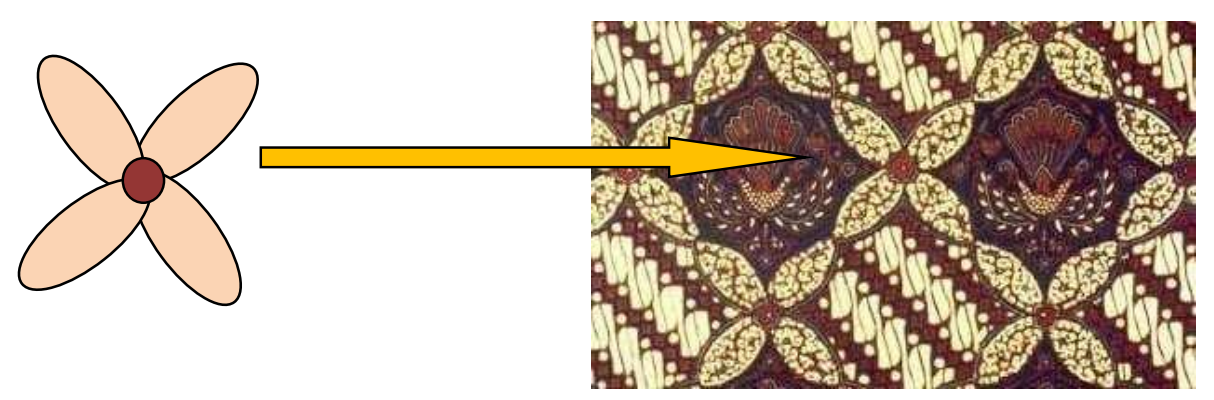

Gambar 6

$>\quad$ Kemudian reflesikan Gambar 6 terhadap sumbu $x$

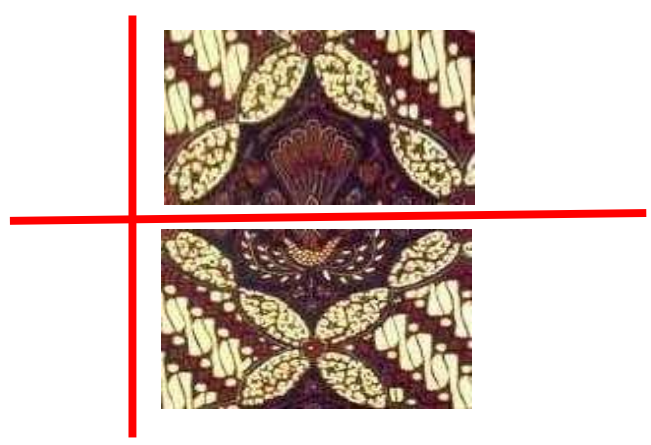

$>\quad$ Kemudian refleksikan Gambar 6 terhadap sumbu y

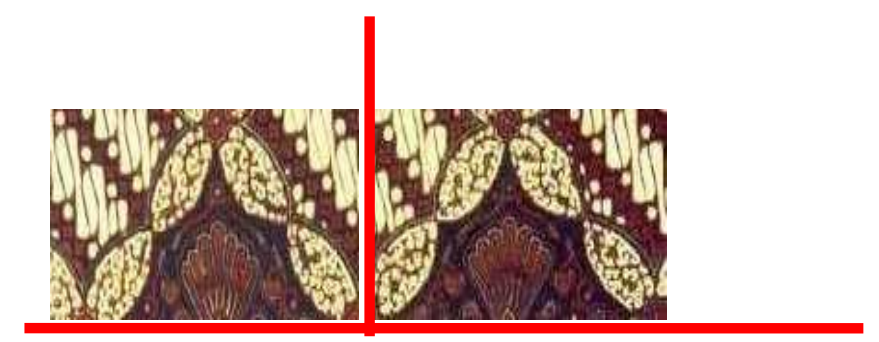

$>\quad$ Kemudian refleksikan Gambar 6 terhadap titik $O(0,0)$ 


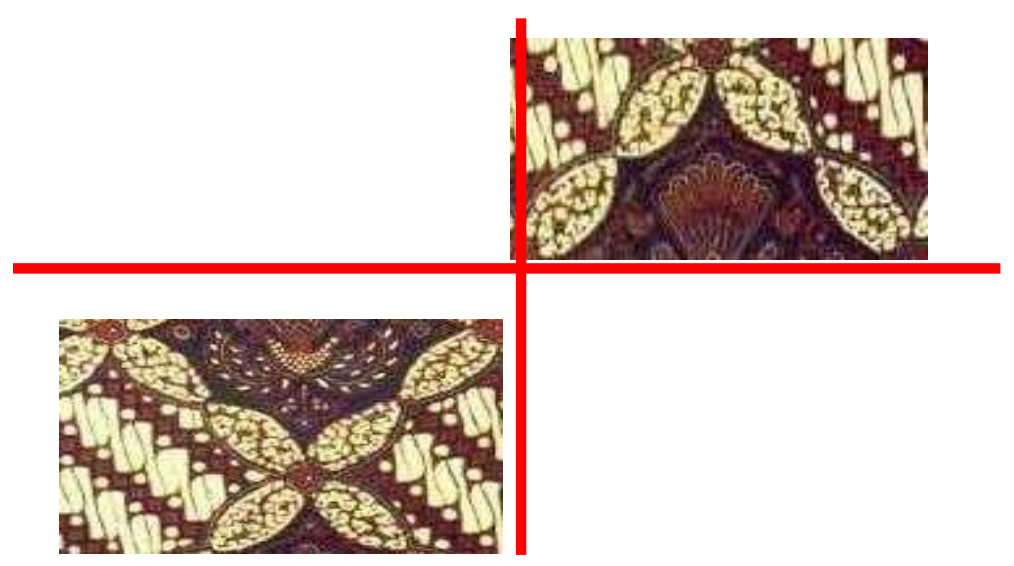

> Sehingga di peroleh Motif Batik Ceplokan seperti gambar 6

c. Implementasi rotasi (perputaran) pada Motif Batik Ceplokan

Perputaran merupakan suatu transformasi yang memindahkan semua titik pada bidang dengan besar sudut tertentu dimana sudut yang dengan searah jarum jam bernilai negatif (-) sedangkan yang berlawanan arah bernilai positif (+). Secara sistematis suatu perputaran didefinisikan bahwa suatu perputaran terhadap titip p dengan sudut $\theta$, dilambangkan dengan $R_{\rho, \theta}$, adalah suatu pemetaan yang memenuhi untuk sembarang a di bidang.[5]

$$
R_{\rho, \theta}\left\{\begin{array}{c}
A, \forall A=P \\
A, \text { dengan }\left|P A^{\prime}\right|=|P A| \\
\text { dan } m\left(<A P^{\prime} A\right), \text { untuk } A \neq P
\end{array}\right.
$$

Pengaplikasiannyanya sebagai berikut:

$>\quad$ Bentuk dasarnya seperti bunga pada Gambar 7

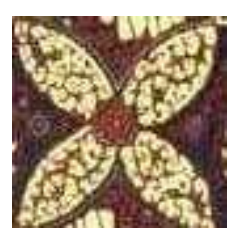

Kemudian rotasikan Gambar 7 sebesar $180^{\circ}$ dengan pusat $O(0,0)$ sehingga Gambarnya menjadi seperti gambar di bawah: 


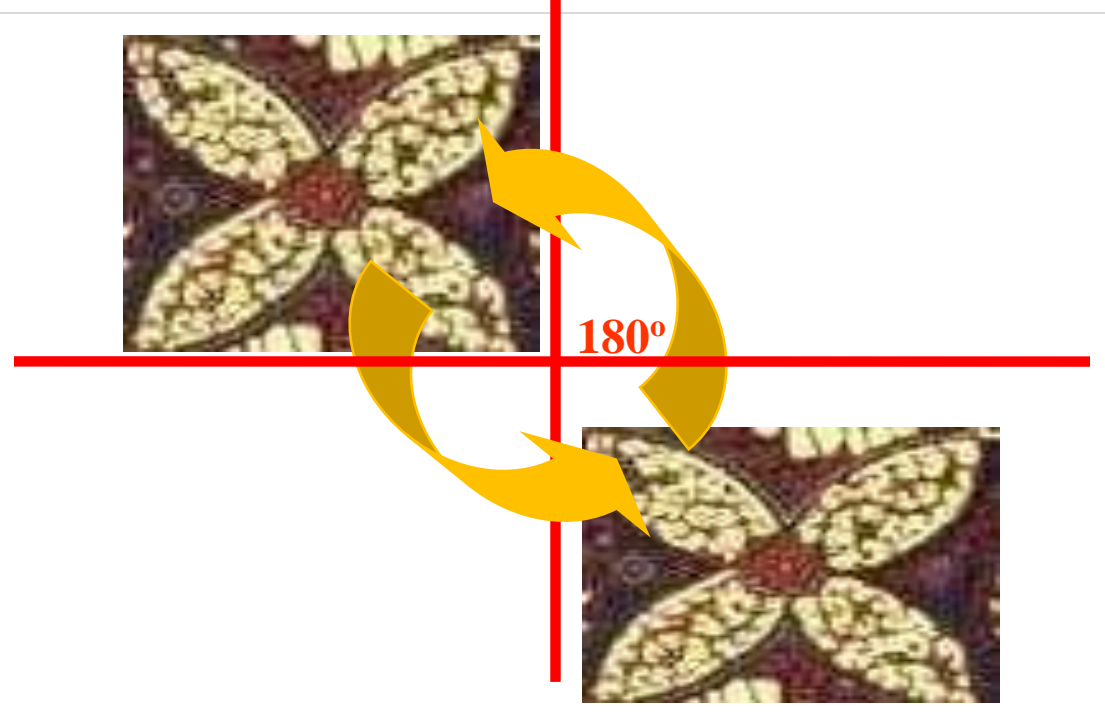

Sehingga ketika di putar sebesar $180^{\circ}$ atau di putar sebesar sudut refleksi maka bentuknya akan sama seperti pada Gambar 1.

d. Implementasi Dilatasi (Perbesaran) pada Motif Batik Ceplokan

Faktor-faktor yang dapat menyebabkan suatu bangun diperbesar atau diperkecil dinamakan faktor dilatasi. Faktor dilatasi dilambangkan dengan $k$ dimana:[5]

- Jika $k>1$ atau $k<-1$, maka diperbesar

- $\quad$ Jika $-1<k<1$, maka diperkecil

- Jika $k=1$ atau $k=-1$, maka bangun tidak mengalami perubahan ukuran

$>\quad$ Kemudian diperbesar ataupun di perkecil dalam Motif Batik Ceplokan, seperti pada gambar di bawah:

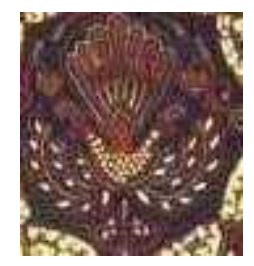

Pemanfaatan etnomatematika yang terdapat dalam karya seni batik yogyakarta motif ceplokan seperti pemaparan diatas dalam pendidikan adalah sebagai alat dalam proses pembelajaran khususnya pada materi geometri transformasi. Dengan adanya motif batik yang mengandung unsur geometri ini dapat digunakan sebagai media untuk memahami sifat translasi (perpindahan), rotasi (perputaran), refleksi (pencerminan) dan dilatasi (perbesaran) pada materi Geometri Transformasi yang terdapat di kelas XI semester ganjil.

Berdasarkan hasil tanya jawab di kelas, guru mengerahkan siswa untuk menarik kesimpulan dari suatu rumusan konsep atau prinsip dari topik yang dipelajari. Deskripsi peningkatan kemampuan pemahaman konsep matematika siswa menggunakan 
etnomatematika pada motif batik ceplokan dari yogyakarta diperoleh hasil posttest, dimana diperoleh hasil seperti pada tabel dibawah ini.

Tabel 1. Data Kemampuan Pemahaman Konsep Siswa Kelas Eksperimen dan Kelas Kontrol

\begin{tabular}{c|c|c}
\hline Keterangan & Kelas Eksperimen & Kelas Kontrol \\
\hline$N$ & 20 & 21 \\
\hline Mean & 75,8 & 65,4 \\
\hline StDev & 11,9 & 10,0 \\
\hline SE Mean & 2,7 & 2,2 \\
\hline
\end{tabular}

Berdasarkan hasil posttest kemampuan pemahaman konsep matematika siswa menunjukkan bahwa rata-rata kemampuan pemahaman konsep peserta didik kelas eksperimen lebih tinggi dibandingkan dengan kelas kontrol, serta mengalami peningkatan dari sebelum diberi perlakuan dengan setelah diberi perlakuan baik kelas eksperimen maupun kelas kontrol. Kaidah pengujian signifikansi untuk uji hipotesis 4 menggunakan One Simple $t$ Test dengan menggunakan program Minitab 16 ialah jika nilai $p<0,05$, maka $H_{0}$ ditolak dan $H_{1}$ diterima artinya terdapat pengaruh yang signifikan, namun jika nilai $p>0,05$ pada uji hipotesis dengan menggunakan uji Ancova, maka $H_{0}$ diterima dan $H_{1}$ ditolak artinya tidak terdapat pengaruh yang signifikan. Berdasarkan analisis data terlihat bahwa sumber perbedaan pengaruh interaktif antara pembelajaran dengan pendekatan matematika realistik berbasis etnomatematika terhadap kemampuan pemahaman konsep, tampak nilai statistik $T-$ Value $=3,03 P-$ Value $=0,002 D F=37$. Oleh karena $P-$ Value $=0,002<0,05$ maka dapat disimpulkan bahwa terdapat peningkatan pemahaman konsep matematika siswa pada materi geometri transformasi yang diajar menggunakan etnomatematika pada motif batik ceplokan yang berasal dari yogyakarta. Artinya $H_{0}$ ditolak dan $H_{1}$ diterima

\section{Kesimpulan}

Pembuatan Motif Batik Ceplokan tidak lepas dari unsur geometri, karena dalam Batik Ceplokan terdapat pengaplikasian dari perpindahan (translasi), pencerminan (refleksi), perputaran (rotasi), dan perbesaran (dilatasi). Penggunaannya pada karya seni batik yaitu dengan menggunakan konsep unsur geometri yang terdapat pada motif Batik Ceplokan. Pola bentuk pada motif batik ceplokan dapat dijadikan sumber belajar matematika bagi siswa. Selain itu, siswa dapat memperoleh wawasan yang berkaitan dengan konsep geometri, dapat menghasilkan karya seni dengan memahami aplikasi geometri transformasi, menambah pengetahuan siswa mengenai adanya matematika pada salah satu unsur budaya khususnya pada karya seni Batik Motif Ceplokan yang mereka miliki, meningkatkan pemahaman konsep matematika siswa dan memotivasi dalam belajar serta memfasilitasi siswa dalam mengaitkan konsep-konsep yang dipelajari dengan kenyataannya. 


\section{Ucapan Terimakasih}

Terimakasih kepada SMA N 01 Bangunrejo yang telah mengijinkan kami melakukan penelitian dan membantu sampai proses pengumpulan data ini terselesaikan.

\section{Pustaka}

Abi Fadila. Penerapan Geometri Transformasi Pada Motif Batik Lampung. Prosiding Seminar Nasional Pendidikan tentang Membangun Generasi Berpendidikan dan Religius Indonesia Berkemajuan,yang diselenggarakan oleh FKIP Universitas Muhamadiyah Metro, ISBN: 978-602-70313-2-6

Afrilianto, M. (2012 ). Peningkatan Pemahaman Konsep dan Kompetensi Strategis Matematis Siswa SMP dengan Pendekatan Metaphorical Thinking . Jurnal Ilmiah Program studi Matematika STKIP Siliwangi Bandung

Arikunto, S. (2010). Prosedur Penelitian Suatu Pendekatan Praktek. Jakarta: Rineka Cipta. Begg, A \& Hamilton. 2001. "Ethnomathematics: Why, and What Else?".ZDM . Volume 33(3), 71-74

Ekowati, D. W., Kusumaningtyas, D. I., \& Sulistyani, N. (2017). Ethnomathematica Dalam Pembelajaran Matematika Pembelajaran Bilangan Dengan Media Batik Madura, Tari Khas Trenggal dan Tari Khas Madura. Jurnal Pemikiran dan Pengembangan SD, 716717

Fitri, R., Helma, \& Syarifuddin, H. (2014). Penerapan Strategi The Firing Line Pada Pembelajaran Matematika Siswa Kelas XI IPS SMA Negeri Batipuh. Jurnal Pendidikan Matematika

Kesumawati , N. (2008). Pemahaman Konsep Matematik dalam Pembelajaran Matematika . Prabawati, M. N. (2016). Etnomatematika Masyarakat Pengrajin Anyaman Rajapolah Kabupaten Tasikmalaya . Jurnal Ilmiah Program Studi Matematika STKIP Siliwangi Bandung , 25

Muchamad Subali Noto. 2015. Efektivitas Pendekatan Metakoginis Terhadap Penalaran Matematis Pada Matakuliah Geometri Transformasi.. (Bandung: Infinity: Jurnal Ilmiah Program Studi Matematika STKIP Siliwangi Bandung, Vol. 4, No. 1)

Rohaeti, E. E. (2011). Transformasi Budaya Melalui Pembelajaran Matematika Bermakna Di Sekolah . Jurnal Pengajaran MIPA . Sariyatun. (2013). Pengembangan Model Pendidikan Nilai-Nilai Budaya Di SMP Berbasis Tradisi Seni Batik Klasik Surakarta. Paramita

Sudirman, Rosyadi, Wiwit Damayanti Lestari. Penggunaan Etnometematika Pada Karya Seni Batik Indramayu Dalam Pembelajaran Geometri Transformasi. (Jurnal Pedagogy, Vol. 2, No. 1) 
Suhartini, \& Martyanti, A. (2017). Meningkatkan Kemampuan Berpikir Kritis Pada Pembelajaran Geometri Berbasis Etnomatematika. Jurnal Gantang, 105

Supriadi, Arisetyawan , A., \& Tiurlina. (2016). Mengintegrasikan Pembelajaran Matematika Berbasis Budaya Banten Pada Pendirian SD Laboratorium UPI Kampus Serang. Mimbar Sekolah Dasar. Tanu, I. K. (2016). Pembelajarana Berbasis Budaya Dalam Meningkatkan Mutu Pendidikan Di Sekolah . Jurnal Penjamin Mutu

Walle. 2007. Pengembangan Pengajaran Matematika Sekolah Dasar dan Menengah. (Jakarta: Erlangga)

Zevika, M., Yarman, \& Yerizon. (2012). Meningkatkan Kemampuan Pemahaman Konsep Siswa Kelas VIII SMP Negeri 2 Padang Panjang Melalui Pembelajaran Kooperatif Tipe Think Pair Share Disertai Peta Pikiran. Jurnal Pendidikan Matematika, 45 